\title{
The Role of Newspaper and State Government in Conservation of World Heritage Site in Malaysia
}

\author{
Mohd Hiriy Ghazali@Mohd Jani (Corresponding Author) \\ Ph.D Student, School of Multimedia Technology and Communication \\ Universiti Utara Malaysia, Malaysia \\ E-mail: mohdhiriy52@gmail.com
}

\begin{abstract}
Abdullah Sumrahadi
Visiting Lecturer, School of Creative Industry Management \& Performing Arts Universiti Utara Malaysia

Lecturer, Faculty of Administrative Sciences

Universitas Krisnadwipayana, Jakarta, Indonesia

E-mail: abdullahsumrahadi@gmail.com
\end{abstract}

Bahtiar Mohamad

Senior Lecturer, School of Multimedia Technology and Communication Universiti Utara Malaysia

E-mail: mbahtiar@uum.edu.my

Received: Feb. 1, 2018 Accepted: Mar.1, 2018 Online published: Mar. 7, 2018

doi:10.5296/jpag.v8i1.12780 URL: https://doi.org/10.5296/jpag.v8i1.12780

\begin{abstract}
Currently, there are two historical sites has been recognized as World Heritage Site by United Nations Educational, Scientific and Cultural Organization (UNESCO) in Malaysia, which are Melaka (Malacca) and George Town, Penang. Since its recognition, those cities becomes so famous and positioned as one of the world tourism attraction that need to visit. In line with this prestige, conservation matter definitely appears to be a major concern especially to both cities in order to maintain the status given. The paper aims to discover the local daily
\end{abstract}


newspaper of The Star in terms of its portrayal of image on the historic or heritage buildings within the areas of World Heritage Site. Content analysis and previous literature were used as the research method. The findings show that indeed the images of photo could influence the public reader and create awareness of the issues raised. Behind the image thus, this paper would also examine at the role of the state in an effort to conserve the historic buildings of these two cities. Studies on image or visual are still rare in the country and therefore, this paper intend to fill this gap by associating it with the cultural heritage conservation in Malaysia.

Keywords: Melaka, George Town, newspaper, image, the role of the state

\section{Introduction}

In July 7, 2008, Malaysia has created another history, in which two of its states were recognized as a World Heritage Site by UNESCO. Both of Melaka and George Town, Penang are currently in the world map, especially in the cultural heritage tourism sector. In fact, the impact of this status not just benefiting to those historical cities, but it also go beyond the country as a whole. Besides Melaka and George Town, Historic Cities of the Straits of Malacca thus, there are three more UNESCO recognition in the country for instance Kinabalu National Park, Sabah and along with Mulu Mountain National Park, Sarawak in 2001 (under the category of Natural Heritage) and also Lenggong Valley, Perak in 2012 (under the category of Archaeological Heritage).

Although research on World Heritage Site at international level has begun since 1945, however studies on the conservation of the World Heritage Site in Malaysia are still lacking (Solihah et al., 2015). This is because it started quite late and in consequence, the awareness of the conservation of heritage or historic buildings were only appears around the 1980s. Hence, this shows that the study is still new and has great potential for further exploration. The paper shall focus only on the conservation of tangible heritage vies a vies historic buildings within the area of World Heritage Sites of Melaka and George Town.

In the Malaysian context, the heritage conservation and tourism development are largely depend on the role of the state, which includes the Federal, State and Local Government (Lai \& Ooi, 2015). Through the federal or central government, the responsible body is for instance National Heritage Department (Jabatan Warisan Negara) - under the Ministry of Tourism and Culture of Malaysia. While as for the local government, especially in both historical cities, there are two bodies who in charge such as Melaka Historic City Council (Majlis Bandaraya Melaka Bersejarah) and City Council of Penang Island (Majlis Bandaraya Pulau Pinang). The last and the foremost one is the state government, in which the bodies responsible for both cities like Conservation Center of Melaka (Pusat Konservasi Negeri Melaka) and George Town World Heritage Incorporated (GTWHI). Apart from that, the country also has a special policy in addressing conservation issues that is the National Heritage Act 2005 (Act 645).

Media consisting of print media, television, radio, and so forth, plays a significant role in disseminating information and creating awareness on certain particular issues raised to the public. In fact, media has the power to reach millions of homes at a time and thus, it may play 
an imperative role in attaining the desired objectives (Showkat, 2016). In the context of this paper, the media refers to the print media that is newspaper. In the west, newspaper readership trends are getting decline and in contrary, daily print circulation continues to increase in Asia, including of Malaysia. Ali et al. (2011) explained the people of this country, still prefer to get their news through the print newspaper and as for the Malay newspapers for instance, it have had an increased circulation currently compared to two decades ago.

According to Soroka (2002) newspaper coverage has an influence on how the public and policy makers come to be aware of, and think about, an issue. Obviously, the ways that issues are framed in newspaper, and how its related to government policies and people's awareness, attitudes, and actions, offer us insight into the mechanism by which a society works, for instance, the relative freedom that journalists have to report on issues (Freeman, 2017). This study aims to examine The Star newspaper portrayal by focusing more on the image rather than text, regarding on the conservation of historic buildings in World Heritage Sites of Melaka and George Town, starting from year 2008 to 2015.

\section{Literature Review}

The importance of conserving the historic buildings is something that cannot be argued. Mustafa et al. (2011) revealed the historic buildings are deemed as highly valuable assets due to their cultural significance as well as tourism potentials. Besides that, both the identity of a nation and people are largely defined by their heritage which is a legacy that is passed down from one generation to another (Sodangi et al., 2011). Numerous cultural and historical significance that are worthy of preservation for sustainable development in Malaysia. However, many of them are subjected to urban modernization (Wan Hashimah, 2012). Furthermore, uncontrolled development has caused in the building of new buildings or facades sandwiched in between of old buildings.

In the west, conservation of historic cities are considered as common situation and in reverse, many of non-western countries are still in dispute over whether to develop or demolish. Meanwhile, both, Pearce (1989) and Kong and Yeoh (1994) acknowledged that conservation in the developing countries had become a minority interest compared to other urban asset development. In fact, conservation is further often seen to be an obstacle to modern development. While, in Malaysia, the sad condition of historical conservation in the country was long left untold and disregarded, until the Federal government recently realized the importance of historic buildings as living evidence of the national growth and success (Shahrul Yani et al., 2013).

According to the Malaysia National Heritage Act 2005 (Act 645) under the section 2 thus, building refers to a building or groups of separate or connected buildings which, because of their architecture, their homogeneity or their place in the landscape, are of outstanding universal value from the point of view of history, art or science. In addition, as for the definition of conservation, it includes of preservation, restoration, reconstruction, rehabilitation and adaptation or any combination thereof (National Heritage Act, 2005). On the other hand, the Melaka Enactment No. 6 (1988) defines conservation as a process of looking after a cultural heritage or a conservation area so as to retain its significance. 


\section{Macrothink}

Journal of Public Administration and Governance ISSN 2161-7104 2018, Vol. 8, No. 1

Historically, the development of historic buildings conservation in this country began in major cities such as Kuala Lumpur, George Town and then followed by Melaka (Solihah et al., 2015). Syed Zainol (1995) elucidates from the findings inventory of historic buildings in Malaysia which has been done by the Department of Museums and Antiquities in 1992 thus, it is estimated there are around 35000 prewar buildings spotted in 265 cities throughout the country under review must be conserved. In addition, A. Ghafar (2009) revealed that most of the historic buildings in the country are not well-preserved and also most of them are in obsolete conditions due to the factor of building damage. Other research for instance by Kamal et al. (2008) argued in spite of the increasing consciousness among the public on the need for conserving the nation's cultural heritage, yet numerous historic buildings are still remain in poor conditions with signs of serious building defects that threatening their survival. Even worse, when there are historic buildings threatened with destruction due to neglected by the real owner and demolished by at the insistence of development as well as less of concern of the community in effort to conserve the historic buildings (Hamilton \& Zuraini, 2002).

A. Ghafar (1994), Feilden (1994) and Yahaya (1996) agreed that historic buildings should be protected because of it has the cultural, emotional and also the use is priceless. Hence, without continuing conservation efforts, this historic buildings are feared would remain to extinction (Ashurts, 2006). In fact, Siti Nor Fatimah et al. (2017) added failure to conserve and manage the country's heritage could lead to enormous losses to the state itself, in particular. Therefore, it is obvious to state that historic buildings are deems to be very valuable to the country and the conservation efforts need to be done constantly by parties involved, especially the Government side in ensuring that those buildings are keep maintained.

\section{World Heritage Site of Melaka and George Town}

Cities of Melaka and George Town were located in different spot and geography. Melaka city located in the mainland of southern part of peninsular, while George Town positioned in Penang Island, on northern part of peninsular, Malaysia (Figure 1). The two historic cities were located on trail trade the Straits of Malacca, are renowned for their multicultural heritage (Siti Norlizaiha \& Izzamir, 2011). In fact, these ports were placed at a strategic location during the period of 15 th to 18 th century. At present, for the category of historic city and yet, only these two of cities that possesses this status in the country (Mohd Hiriy et al., 2017). 


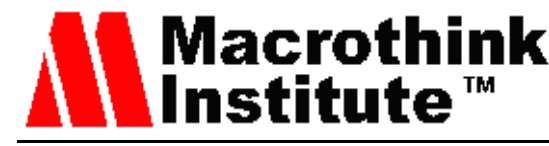

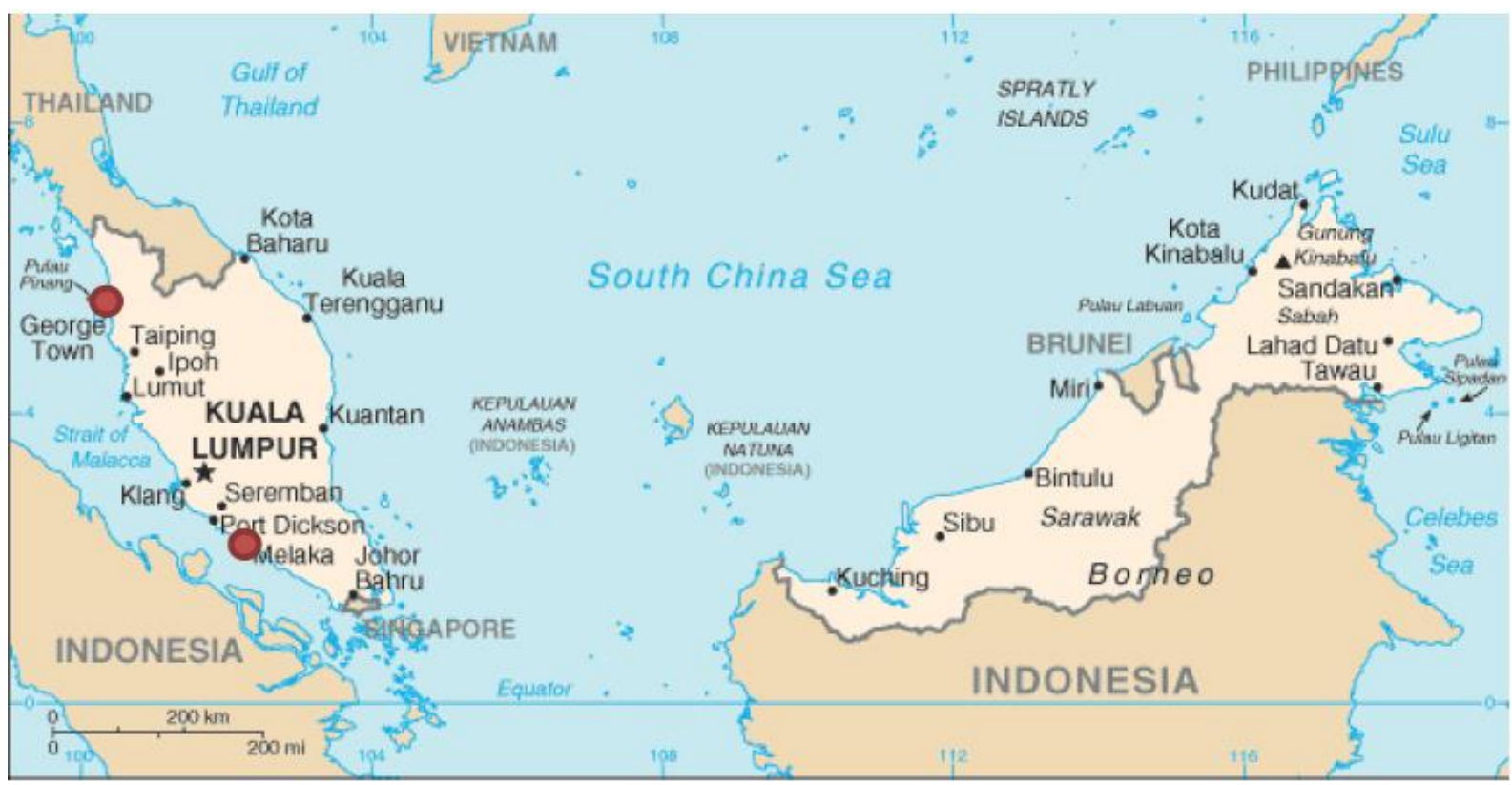

Figure 1. Location of Melaka and George Town

Literally, both of historic cities display testimony to a living multi-cultural heritage as well as custom of Asia, where the numerous religion and culture met and exist together. They reflected the coming together of cultural aspects from the Malay Archipelago, India, China and also with those of Europe, to create a unique architecture, townscape as well as culture (Siti Norlizaiha \& Izzamir, 2011). Thus, both cities have fulfilled some of the criteria set by UNESCO (2018) with regards to its Outstanding Universal Value and further details are as follows:

(ii) Melaka and George Town represent exceptional examples of multi-cultural trading towns in East and Southeast Asia, built up from the commerce and exchanges of Malay, Chinese, and Indian cultures as well as three successive European colonial powers 500 years, each with its imprints on the architecture and urban form, technology and monumental art. Both towns show different stages of development and the successive changes over a long span of time and are thus complementary.

(iii) Melaka and George Town are living testimony to the multi-cultural heritage and tradition of Asia, as well as European colonial influences. This multi-cultural tangible and intangible heritage is expressed in the great variety of religious buildings of different faiths, ethnic quarters, the many languages, worship and religious festivals, dances, costumes, art and music, food, and daily life.

(iv) Melaka and George Town reflect a mixture of influences which have created a unique architecture, culture and townscape without parallel anywhere in East and South Asia. Notably, they demonstrate an exceptional range of shop houses and townhouses. These buildings show many different types and stages of development of the building type, some originating in the Portuguese or Dutch periods.

In brief, both cities are associated to the existence of all the elements necessary to 


\section{$\triangle$ Macrothink}

Journal of Public Administration and Governance

ISSN 2161-7104

demonstrate their 'Outstanding Universal Value'. Outstanding universal value refers to cultural and/or natural significance which is so exceptional as to transcend national boundaries and to be of common importance for present and future generations of all humanity (World Heritage Convention, UNESCO 2017). Therefore, the permanent protection of this heritage is of the highest importance to the international community as a whole and also for the role of state, in particular. Melaka and George Town have a tough task to do in order to maintain the status given that is by conserving and preserving their heritage spots, especially within the core zone areas (Figure $2 \& 3$ ) subject to as outlined by UNESCO.

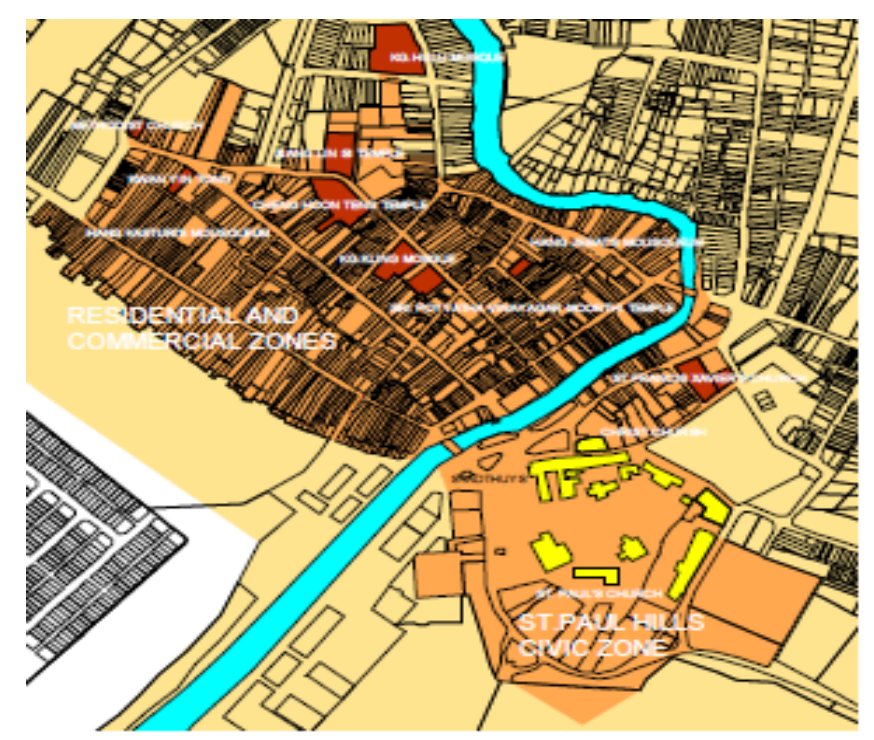

Figure 2. Core Zone of Melaka

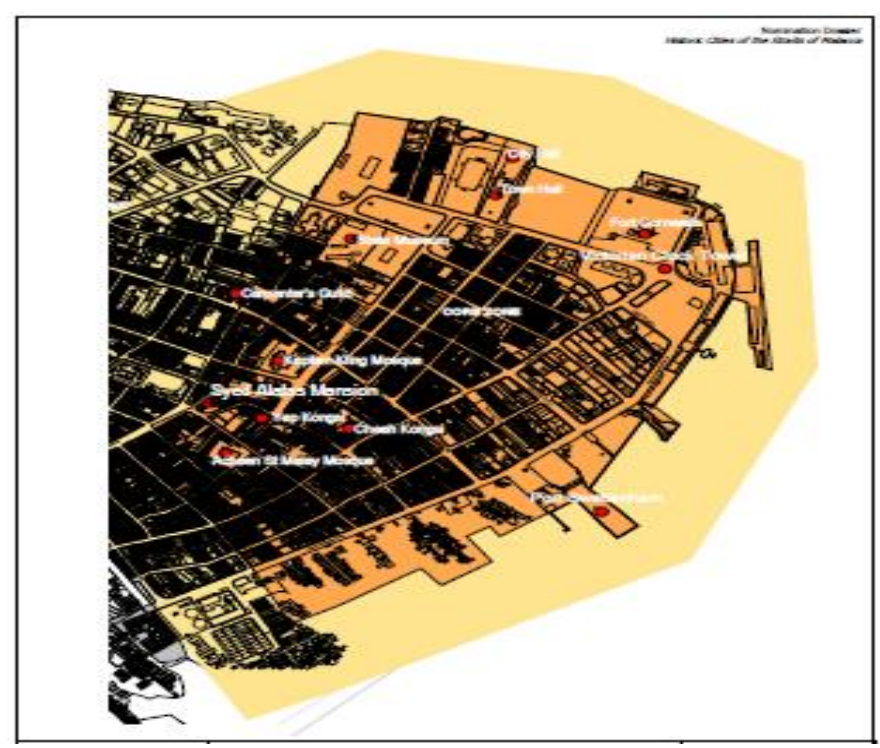

Figure 3. Core Zone of George Town

\section{Research Method}

The paper used content analysis as a main technique and it is based on qualitative approaches. A local daily newspaper selected is in English language, namely The Star. The reason for 


\section{Macrothink}

choosing the newspaper because it is deemed as the leading English language daily in the country. In addition, the period of time for newspaper coverage is approximately seven (7) years, 2008 to 2015 . These years were chosen due to purpose for investigate the images portrayed from this newspaper which concerning on the conservation of historic buildings, particularly in Melaka and George Town. Apart from that, to scrutinize the trend of images portrayal starting from its recognition on July, 2008 to upwards. Next is from the previous literature, which emphasizes more on the role of the state government regarding conservation of historic building.

\section{Analysis and Discussion}

From the data findings, total of images from The Star newspaper show as in Table 1.

Table 1. The Star Newspaper Portrayal of Images

\begin{tabular}{c|c|c|c|c}
\hline Year & $\mathbf{2 0 0 8}$ & $\mathbf{2 0 1 0}$ & $\mathbf{2 0 1 1}$ & $\mathbf{2 0 1 5}$ \\
\hline Month & $13 \& 23$ July & $\begin{array}{c}\text { 22 February, } 8 \\
\text { July \& 19 } \\
\text { November }\end{array}$ & $\begin{array}{c}24 \\
\text { September }\end{array}$ & 2 March \\
\hline Quantity & 2 & 3 & 1 & 1 \\
\hline
\end{tabular}

Table 1 shows the images from The Star coverage, which are related or close to the conservation of historic buildings of Melaka and George Town. Seven (7) out of seventeen (17) images have had obtained from data collection, in overall. Four of them portray of Melaka historic city, and the remaining three images represent George Town. Although there are seven images, but not all of them portraying directly to historic buildings. This being the case, because some of those images also portraying it indirectly. Due to lack of data related to images, this paper just concentrates only on the images that portray directly on the conservation of historic buildings, and not the other way around. Therefore, only two images were picked and each one of its represent of both historical cities and the details are follows. Image 1 illustrates a historic building in the Melaka and from another side; image 2 also portrays similar things in George Town (The Star, 2015, March 02 \& 2010, November 19). Besides that, it is imperative to note that the portrayal of these images is also mixed with the text. 


\section{Fire destrioȳs six heritage buildings}

Only front facade left standing after the morning blaze at double-storey shoplots
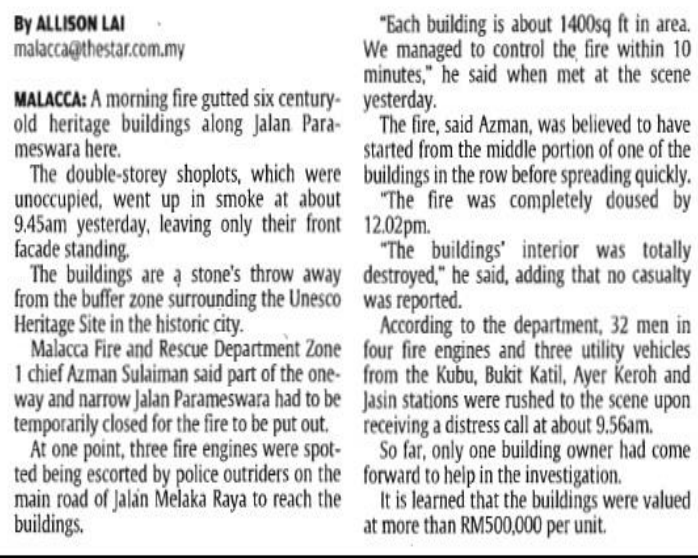

The fire, said Azman, was believed to have started from the middle portion of one of the buildings in the row before spreading quickly. "The fire was completely doused by $2.02 \mathrm{pm}$.

"The buildings' interior was totally destroyed," he said, adding that no casualty was reported.

According to the department, 32 men in four fire engines and three utility vehicles from the Kubu, Bukit Katil, Ayer Keroh and Jasin stations were rushed to the scene upon receiving a distress call at about $9.56 \mathrm{am}$.

So far, only one building owner had come forward to help in the investigation.

It is learned that the buildings were valued at more than RM500,000 per unit.

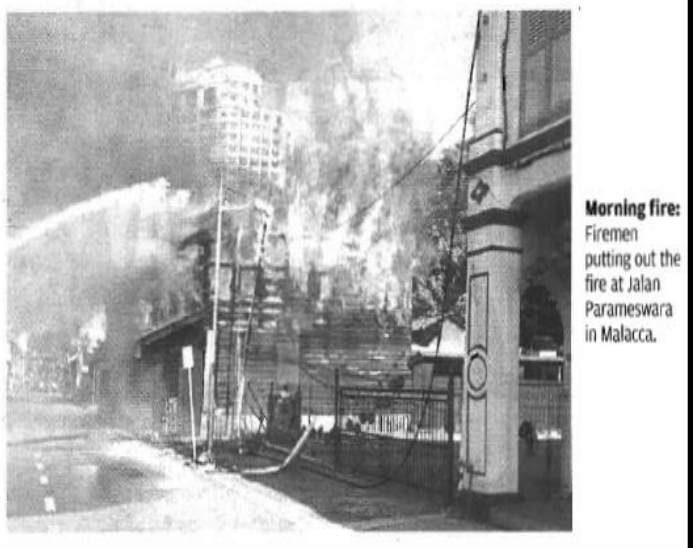

Figure 4. Image 1 of Melaka

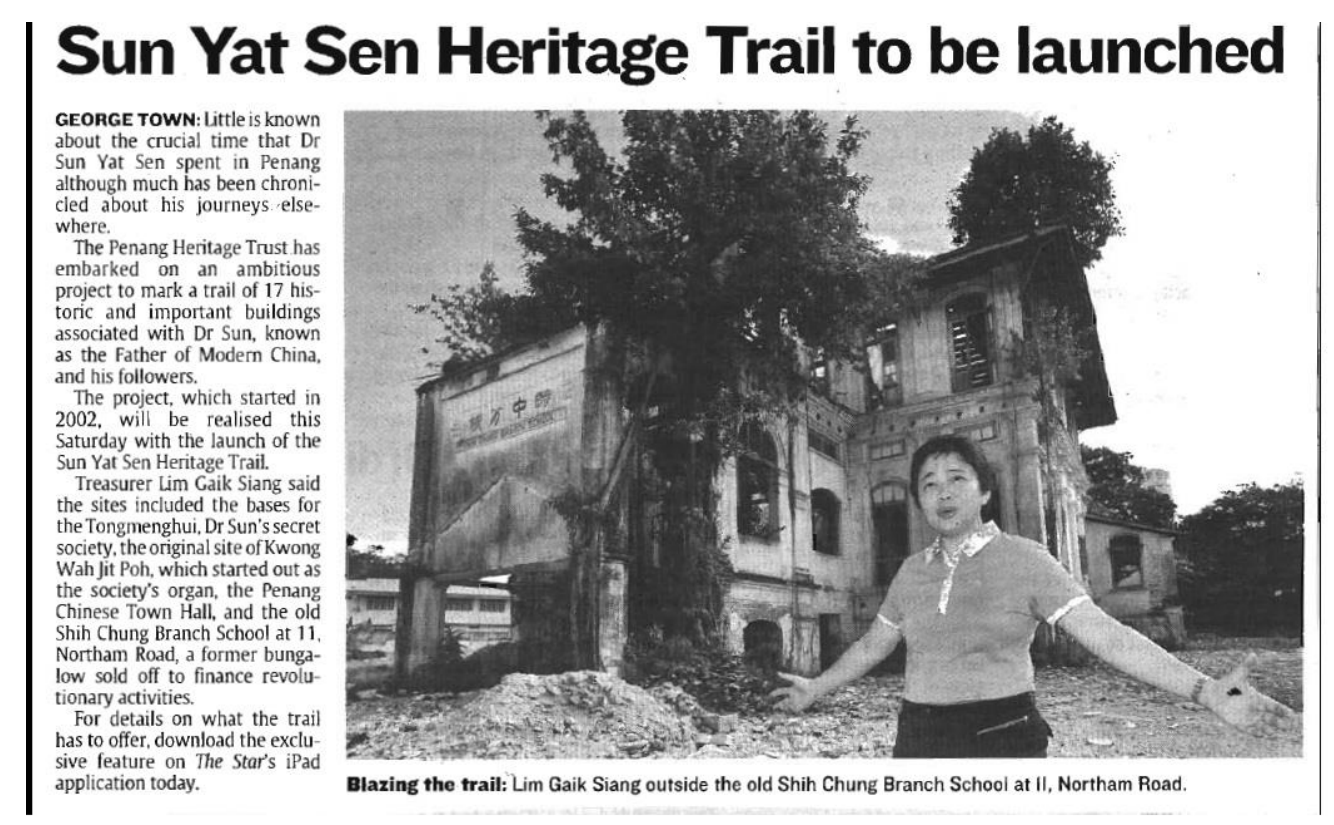

Figure 5. Image 2 of George Town

From the Image 1, it shows the condition of historic or heritage buildings in Melaka are on fire. Literally, these buildings are seemed to be empty and unoccupied. In addition, these double-storey shop lots buildings are also seem to be abandoned by their owner. The loss is estimated around Ringgit Malaysia (RM) 500000 per unit and based on the news report, there are about six burnt buildings identified. Interestingly to point out, even though the area is not specifically located within the core and buffer zone, but bear in mind that the position of this spot actually is very close to its (the distance like stone's throw away). This is a certainly becomes a major concern for us because of fear that if it is not well controlled, then 
later it will destroy other historic buildings too, especially that located in the core and buffer zone of world heritage site of Melaka.

On the other hand, Image 2 illustrates an old building that seems to be neglected. By seeing through this image thus, it is clear to say that this building appears to be not well taken care of by the authorities. There are some erosion and overgrown tree on the building and besides, some windows are damaged as well as the ground looks empty without any decorative landscaping. It is believed that this building and along with the other 16 historic buildings had a connection with the heritage trail of Dr. Sun Yat Sen (better known as father of modern China). Hence, taking into account the benefits of history as well as the status of world heritage site, it is better if the building is preserved and well managed so that it would be one of the main attractions for tourists to visit here.

Based on the two images above, it can be summarized that the newspaper portrayal via text or image is very significant in influencing readers with a particular issue. In fact, both images also give a symbolic sign especially to the related parties regarding how important to protect historic buildings and then take necessary action to prevent it from damage. Therefore, this paper will explore in depth concerning what is behind the displayed image so that to get a clearer explanation of it. Next discussion is about the role of the state and the details are as follow.

\section{The Role of the State}

In this setting of context, the role of the state actually refers to the state government of Melaka and Penang. Since its recognition as UNESCO world heritage site in July, 2008 thus, both historical cities have made conservation as their main agenda (The Star, 2008, July 09 \& November 23). In this regard, the state government of Melaka and Penang have a heavy responsible in order to ensure that historic buildings are constantly preserved and maintain the status granted as long as possible.

\subsection{The State Government of Melaka}

Historically, conservation plan was first identified for area of conservation in 1979. Next in 1988, the state government of Melaka organized a seminar on heritage and then finally decided to nominate the St Paul's Hill as a heritage zone after the seminar. At the meantime, the historic buildings within the zone comprise of A Famosa fort, Dutch Stadthuys building and Christ Church has been conserved and restored.

Melaka has an enactment to safeguard its cultural heritage, namely the Preservation and Conservation of Cultural Heritage Enactment, 1988 (Siti Norlizaiha \& Izzamir, 2011). Basically, the enactment covers inclusive aspects of conservation and restoration for cultural heritage in Melaka. In addition, the Conservation Trust Fund was formed in 1993, where this enactment is placed under the Melaka Museums Corporation. Meanwhile, the State Structure Plan of Melaka has identified Melaka heritage sites, in 2001. As a result, Melaka has listed two protected areas within the conservation zone for instance St Paul's Hill Civic Zone as well as Historic Residential and Commercial Zone which have funds for conservation project from the Conservation Trust Fund and also Federal Government. Based on Application Dossier for Registration of Historic Cities of the Straits of Melaka and George Town (2007), it has explained in detail the planning of the state of Melaka (Table 2). 
Table 2. List of Melaka State Government Plans in Preserving the Heritage Entities

\begin{tabular}{|c|c|c|}
\hline Plans & Status & Provisions \\
\hline $\begin{array}{l}\text { Melaka } \\
\text { Council } \\
\text { Structure } \\
\text { Plan }\end{array}$ & & $\begin{array}{l}\text { Prepared in year 1993, this study was prepared by the } \\
\text { Federal Town and Country Planning Department } \\
\text { (FTCPD), according to the development plan system } \\
\text { empowered by the } 1976 \text { Town and Country Act (Act } \\
\text { 172). The structure plan covered the existing historic } \\
\text { fundamental as the study area and was prepared for a } \\
10 \text { years' time period (1991 to 2001). The salient } \\
\text { contents of the structure plan are extensive policies } \\
\text { and proposals governing the various components } \\
\text { such as land use, housing, tourism, conservation, } \\
\text { transportation, infrastructure and utilities. } \\
\text { Basically, the tourism policies recommended in the } \\
\text { structure plan had focused on the redevelopment of } \\
\text { the dockland or quayside area for tourism purposes } \\
\text { and turning Melaka into a 'living museum'. } \\
\text { Above all, the structure plan delineated a } \\
\text { Conservation Area covering the civic area and old } \\
\text { area which was subsequently gazette by the state } \\
\text { using the Preservation and Conservation of Cultural } \\
\text { Heritage Enactment, 1988, for Melaka state. }\end{array}$ \\
\hline $\begin{array}{l}\text { Melaka } \\
\text { State } \\
\text { Structure } \\
\text { Plan }\end{array}$ & $\begin{array}{l}\text { Adopted by the } \\
\text { Historic City of } \\
\text { Melaka Municipal } \\
\text { Council and Melaka } \\
\text { State } \\
2002\end{array}$ & $\begin{array}{l}\text { For the first time in Malaysia, a structure plan } \\
\text { comprised a section on conservation of heritage } \\
\text { resources for the state of Melaka. The plan elaborates } \\
\text { the strategies for heritage protection especially } \\
\text { focusing on the Core Zone and has become the } \\
\text { foundation for more specific guidelines in the Local } \\
\text { Plan. } \\
\text { Initially, the Melaka Structure Plan (review) was } \\
\text { supposed to be a review of the Melaka Structure Plan, } \\
1993 \text {, as required by Act } 172 \text {. However, amendments } \\
\text { to Act } 172 \text { (Amendments, } 2000 \text { ) require structure } \\
\text { plans to cover the geographical boundary of the } \\
\text { whole state, instead of the municipality or } \\
\text { administrative area. Thus, the Melaka Structure Plan } \\
\text { is the first state broad structure plan to be prepared in } \\
\text { the whole country and the draft final report was } \\
\text { completed in } 2002 \text { while the public exhibition } \\
\text { exercise was carried out between January to February } \\
2003 \text {. } \\
\text { The State of Melaka Structure plans has a time period } \\
\text { of } 20 \text { years (2000 to } 2020 \text { ) and covers } 15 \text { land use } \\
\text { sectors in which special attention was given to } \\
\text { conservation as well as tourism. Upon its } \\
\text { gazettement, the State of Melaka Structure Plan, } 2002 \\
\text { will provide the legal instrument for managing the } \\
\text { overall development within the Melaka state based on } \\
\text { the principles of sustainable development. }\end{array}$ \\
\hline Local Plans & $\begin{array}{l}\text { Adopted in } 2001 \text { and a } \\
\text { revised version } \\
\text { prepared in } 2006\end{array}$ & $\begin{array}{l}\text { Detailed plans for specific areas covering a range of } \\
\text { subject matters- coverage on heritage conservation. } \\
\text { Actually, the local plan was prepared by the FTCPD } \\
\text { in accordance to Act } 172 \text {. However, the main } \\
\text { highlight was the interpretation of the broad policies } \\
\text { formulated in the structure plan into site specific land } \\
\text { use proposals and development guidelines, covering } \\
2 \text { specific areas within the municipality. Block } 1 \\
\text { consists of the central area including the historical }\end{array}$ \\
\hline
\end{tabular}


core, while Block 2 involves the areas within the urban fringe.

Specific land use proposals and guidelines were formulated for the various land use sectors containing tourism and conservation. Conservation was grouped together with urban design and landscaping. Yet, the local plan was never gazette, and therefore, it could not provide a legal assistance for the Melaka Historic City Council to manage development within its area.

\subsection{The State Government of Penang}

From the historical point of view, the first conservation guideline for George Town in 1987 was 'Design Guidelines for Conservation Areas in Inner City of George Town, Penang'. In year 1989, the State Authority approved the Municipal Council of Penang Island Structure Plan, 1987. In fact, the Historic City of George Town conservation area also had been identified under the Municipal Council of Penang Island's Structure as well as Local Plan. At this stage, it had no exact legislation designed for the protection of heritage buildings. Following, the Municipal Council of Penang Island introduced 'Guidelines for Conservation Areas and Heritage Building in George Town' that replaced and cancelled 'Design Guidelines for Conservation Areas in Inner City of George Town, Penang'. This guideline provides a comprehensive statement of the state government's policy for the identification and protection of historic buildings, conservation areas and other components of the historic environment. Besides that, the local authority refers to Town and Country Planning Act 172, 1976 and Amendment in 1995, and Local Authority Act 171, 1976, to protect the heritage areas as well as properties.

Furthermore, the Penang Structure Plan (2005-2020) suggests that cultural resources should be developed as the unique tourism product for the state. For years, the visitors in Penang have been exposed to multi-cultural heritage like the Malay and Muslim enclave, the Chinese clan houses, the 'Little India' and also experience the living heritage in the inner city (Siti Norlizaiha \& Izzamir, 2011). Next is about the details of Penang state government plans. Again, Application Dossier for Registration of Historic Cities of the Straits of Melaka and George Town (2007) also revealed about the planning of the state of Penang (Table 3).

Table 3. List of Penang State Government Plans in Preserving the Heritage Entities

\begin{tabular}{l|l|l}
\hline \multicolumn{1}{c|}{ Plans } & \multicolumn{1}{|c}{ Status } & \multicolumn{1}{c}{ Provisions } \\
\hline $\begin{array}{l}\text { Penang Island Structure Plan } \\
2020\end{array}$ & $\begin{array}{l}\text { Adopted by the Municipal } \\
\text { Council of Penang Island } \\
\text { and the Penang State } \\
\text { Government }\end{array}$ & $\begin{array}{l}\text { Broad principles and policies } \\
\text { regarding land development. }\end{array}$ \\
\hline $\begin{array}{l}\text { Penang Strategic Development } \\
\text { Plan II }\end{array}$ & $\begin{array}{l}\text { Adopted in year 2001 } \\
\text { Penang Island Local Plans }\end{array}$ & $\begin{array}{l}\text { Economic development } \\
\text { through the sustainable } \\
\text { development approach. }\end{array}$ \\
\hline
\end{tabular}




\section{Conclusion and Recommendations}

Indeed, picture can be regard as the most common way of spreading information, making an impact, expressing oneself, and influencing others. Obviously, an emphasis on visual images does not mean that words (texts) are less important than images. Lester (2000) revealed the most meaningful and powerful messages are combined with words and picture equally. Although the results of this paper shows that the number of images is not that much, but it is still considered significant. Nevertheless, it is expected in the future, the number of images portrayal from newspapers would continue to increase in line with the verbal texts. Nowadays, portrayal of heritage images becomes a selling point, apart from evoking emotions as well as visualization (Luque-Martinez et al., 2007). Therefore, future researchers should extend this study using the latest year to see whether there is a change or not in relation to the trend of portraying heritage conservation images, especially within world heritage sites in the country.

The findings also uncover that the state government of Melaka and Penang have a systematic historic buildings conservation plan, based on legal provisions. However, there is concern over the question of policies enforcement as well as to have balance between modern and heritage development from the state government (Ang Kean, 2015; Wan Hashimah, 2012; The Star, 2008, April 25, July $09 \&$ 13). Certainly, conservation requires continuous effort and huge funding. Therefore, all parties should play their respective roles starting from federal government, state and local governments, non-governmental organizations (NGOs) and the community itself, so that to get a more effective impact on the conservation of world heritage site in both historical cities.

\section{References}

Ali, S., Faridah, I., Mohd, Y. A., Normah, M., \& Maizatul, H. M. (2011). The impact of new media on traditional mainstream mass media. The innovation journal: The public sector innovation journal, Article 7, 16(3), 1-11.

Ang, K. H. (2015). Nota penyelidikan, Melaka sebagai pusat pelancongan dunia: Dapatkah dipertahankan. GEOGRAFIA Online ${ }^{T M}$ Malaysian Journal of Society and Space, 11(9), 75-85.

Ashurts, J., \& Ashurt, N. (2006). Practical building conservation series: Wood, glass and resins. Gower Technical Press: England, (Volume 5).

Feilden, B. M. (1994). Conservation of historic buildings. Oxford: Butterworth.

Freeman, B. C. (2017). Claims, frames, and blame: Coverage of climate change in ASEAN's English language newspapers, 2002-2012. SAGE Open, January-March 2017, 1-12. https://doi.org/10.1177/2158244016675199

Ghafar, A. A. (1994). Why buildings decay? Available: http://www.hbp.usm.my/conservation/ (November 20, 2017).

Ghafar, A. A. (2009). Celebrating Malaysia's world heritage sites: The historic cities of Melaka and George Town. ACCU Nara International Correspondent: The second and the 
Third Regular Report. Cultural Heritage Protection Cooperation Office, Asia/Pacific Cultural Centre for UNESCO (ACCU), Nara, Japan, 8-9.

Government of Malaysia. (2007). Application dossier for registration of historic cities of the Straits of Melaka and George Town. Government of Malaysia Printing Office.

Hamilton, W. N., \& Zuraini, M. A. (2002). The role of building surveyors in conservation works. Proceedings of the 2nd National Conference on Building Control, Petaling Jaya, Malaysia, 22 \& 23 January.

Kamal, S. K., Wahab, A. L., \& Ahmad, G. A. (2008). Pilot survey on the conservation of historical buildings in Malaysia. Proceedings of the 2nd International Conference on Built Environment in Developing Countries, Penang.

Kong, L., \& Yeoh, B. S. A. (1994). Urban conservation in Singapore: A survey of state policies and popular attitudes. Urban Studies, 31(2), 247-265. https://doi.org/10.1080/00420989420080231

Lai, S., \& Ooi, C. S. (2015). Experiences of two UNESCO World heritage cities: National and local politics in branding the past. CLCS Working Paper Series, April, 1- 21.

Lester, P. M. (2000). Visual communication: Images with messages (2nd ed.). Wadsworth.

Luque, M. T., Del Barrio, G. S., Ibanez, Z. J. A., \& Molina, M. A. R. (2007). Modelling a city's image: The case of Granada cities, 24(5), 335-352.

Malaysia. (2006). National heritage act 2005 (Act 645). Percetakan Nasional Malaysia Bhd.

Melaka enactment no. 6. (1988). Preservation and conservation of cultural heritage enactment, 1988.

Available:

http://www.hbp.usm.my/conservation/laws/malacca\%20enactment.html (November 11, 2017).

Mohd, H. G., Abdullah, S., \& Bahtiar, M. (2017). The involvement of state government, agencies and local authority policies on the conservation of heritage spots in Malaysia. Journal of Government \& Politics, 8(3), 327-351. http://dx.doi.org/10.18196/jgp.2017.0051.327-351

Mustafa, N. K. F., Johar, S. Ahmad, Zulkarnain, A. G. S. H., Rahman, M. Y. A., \& Che, A. A. I. (2011). Conservation and repair works for traditional timber mosque in Malaysia: A review on techniques. World Academy of Science, Engineering and Technology, 77, 81-89.

Pearce, D. (1989). Conservation today. New York: Routledge.

Shahrul, Y. Z., Hasnizan, A., \& Elma, D. I. (2013). Heritage conservation and regeneration of historic areas in Malaysia. Asia Pacific international conference on environment-behavious studies, university of Westminster, London. Procedia-Social and behavioural sciences, 105, 418-428. Available: https://www.sciencedirect.com/ (November 15, 2017).

Showkat, N. (2016). Coverage of sanitation issues in India. SAGE Open, October-December 
2016, 1-6. https://doi.org/10.1177/2158244016675395

Siti Norlizaiha, H., \& Izzamir, I. (2011). The conservation plan for world heritage site: George Town, Penang and Malacca, Malaysia. The 1st International Conference on Rebuilding Place: From Culture to Art and Architechture, University Kuala Syiah, Banda Acheh, Indonesia, 4 October.

Siti, N. F. Z., Mohammad, A. A. R., \& Zainal, A. A. (2017). Current issues and future challenges in heritage building maintenance at Malaysia: Literature review. Journal of Humanities, Language, Culture and Business (HLCB), 1(4), 13-21. Available: http://www.icohlcb.com/ (December 15, 2017).

Sodangi, M., Idrus, A., \& Khamidi, F. M. (2011). Examining the maintenance management practices for conservation of heritage buildings in Malaysia. National Postgraduate Conference, Energy and Sustainability: Exploring the Innovative Minds. Perak: Universiti Teknologi PETRONAS. https://doi.org/10.1109/NatPC.2011.6136372

Solihah, M., Mazdi, M., Ruzanna, S. R., Jabil, M., Mohammad, K. Z. A., \& Mohamad, P. Y. (2015). Pengurusan bandar warisan UNESCO dan penglibatan komuniti tempatan: Kajian kes di George Town, Pulau Pinang. GEOGRAFIA Online ${ }^{T M}$ Malaysian Journal of Society and Space, 11(12), 87-99.

Soroka, S. N. (2002). Issue attributes and agenda-setting by media, the public, and policymakers in Canada. International journal of public opinion research, 14, 264-285. https://doi.org/10.1093/ijpor/14.3.264

Syed, Z. A. I. (1995). Pemeliharaan warisan rupa bandar: Panduan mengenali warisan rupa bandar berasaskan inventori bangunan warisan Malaysia. Kuala Lumpur: Badan Warisan Malaysia.

The Star. (02 March 2015). Fire destroys six heritage buildings.

The Star. (09 July 2008). Conservation is top priority: George Town, Malacca have job to do.

The Star. (13 July 2008). Living heritage too must be preserved.

The Star. (19 November 2010). Sun Yat Sen heritage trail to be launched.

The Star. (23 November 2008). George Town and Malacca receive world heritage site award.

The Star. (25 April 2008). Call to preserve cultural heritage.

UNESCO. (2017). Operational guidelines for the implementation of the world heritage convention. Available: http://whc.unesco.org/en/guidelines (January 5, 2018).

UNESCO. (2018). Melaka and George Town, Historic cities of the Straits of Malacca. Available: http://whc.unesco.org/en/list/1223 (January 5, 2018).

Wan Hashimah, W. I. (2012). Sustainability of buildings in historic city of Malacca. ASIAN Journal of Environment-Behaviour Studies, 3(10), October, 57- 69. 
Yahaya, A. (1996). Some aspects of building conservation in Malaysia. Pustaka Kajian Pemuliharaan Bangunan: Universiti Malaya.

\section{Copyright Disclaimer}

Copyright for this article is retained by the author(s), with first publication rights granted to the journal.

This is an open-access article distributed under the terms and conditions of the Creative Commons Attribution license (http://creativecommons.org/licenses/by/4.0/). 